\title{
African Shea Butter as a Staple and Renewable Bioproduct
}

\author{
Kaana Asemave', Tabitha Amarkasev Asemave ${ }^{2}$ \\ ${ }^{1 \& 2}$ Department of Chemistry, Benue State University, Makurdi- Nigeria
}

\begin{abstract}
The world is really making a turn to natural and bioderived chemicals/products. This is so in order to enhance sustainability of the socioeconomic growth, conservation of the environment and human safety. Shea butter is a renewable bioproduct which is traditionally and industriallyused for many medical, personal care and cosmetic applications and so on.More so, shea butter can be a great solution to skin diseases in these days of acute weather and climatic conditions because of its effectiveness and nontoxic nature. The shea tree from which the shea butter is derived, is cultivated orgrown widely and naturally in West and Central Africa in the semiarid Sahel. This tree is an important natural resourcewhich should be seriouslyprotected to sustainthe shea butter derived from it.In addition, there is need for more participation in the shea butter business to maximize its beneficial values. The extraction of butter can be alternatively carried out by using greener solvents preferably supercritical carbon dioxide $\left(\mathrm{scCO}_{2}\right)$ instead of hexane to enhance the quality of the butter.Thus, shea butter is essentially valuable and nontoxic bio-renewable product. The benefits and applications of shea butter cannot be over emphasised and are indispensable and inexhaustive.
\end{abstract}

Keywords: Shea butter, renewable bioproduct

\section{Introduction}

Shea treeis cultivated or grown widely and naturally in West and Central Africa in the semi-arid Sahel[1], [2].It starts to bear fruit after about 20 years and continue to produce nuts for up to 200 years[1].The common varieties of this nut are; Vitellaria paradoxa and Vitellaria nilotica; whereVitellaria paradoxa is more largely grown and marketed.Vitellaria nilotica is predominantly produced in northern Uganda and southern Sudan. The specie, Vitellaria paradoxa of the shea tree grows extensively in Senegal and Uganda, where it is protected and managed[3].The solid fat (butter or stearin) and the liquid oil (olein)products are obtained from shea nut[1]. Shea tree fruit has sweet edible pulp and nut. Shea tree was first described by Moroccan traveller and scholar Battuta as far back in 1348[2], while botanical characteristics of shea tree and the derivationof butter from it was described by the first European that visited the Niger River, Scot Mungo park[4].Shea butter is being staple of African pharmacology.Benin, Ghana, Burkina Faso, and Cote D'Tvoire are major producers of the peculiar species ( $V$. paradoxa. nilotica)[5].The shea fruits are known as Chamen, Kandayi/Makande, Osisi/Okwuma, Emi/Orioyo etc in Tiv, Hausa, Igbo, and Yoruba natives of Nigeria respectively[5].Maranz et al., 2004 had demonstrated the existence of three kinds of shea butter based on fat profile. The one with high stearin $(\mathrm{St}: \mathrm{O}>1)$ is classified as hardbutter found in Burkina Faso and Ghana.The soft-butter with mid-range stearin (St:O,0.7 - 1.0) isgrown in West and East of the hard butter zone. Also there a very soft-butter or liquid-oil which has high olein content $(\mathrm{St}: \mathrm{O}<0.7)$ along the northern Uganda. This has provide choice of locations where a particular butter for specific applications[3]. The shea kernel from Northern Ghana and Burkina Faso is particularly valued for its high stearin and total fat content[3].The main importance of the shea tree (Vitellaria paradoxa) is due to the oil or fat (shea butter) that can be extracted from the dried kernels[3], which has not been well maximized. More so, the harvesting of the shea fruits is most times locally performed by women without enough knowledge on maintaining the quality of these nuts for the extraction of the butter. Worst of it is that, a lot of these nuts are abandoned in fields due to poor investment in this business. Looking at the numerous values of shea butter, it is important to invest into the business so as to improve on the quality and quantity of shea butter for our use.Moreover, there is dearth of quality literature on the holistic processing of shea fruits and nuts. Thus, this review emphasises the need for maximising the production of this indispensable and bio-renewableproduct, shea butter.

\section{Extraction of Shea Butter from the Shea Nuts}

The mature shea fruit are collected between July - August, followed by grading, sorting and cleaning to obtain high quality fruits. Thereafter the fruits arede-pulped; removal of fleshy mesocarp which is facilitated by fermentation. Burrying the fruits in pits which cause the pulp to ferment, disintegrate and produce enough heat that prevent germination of the fruits. Nut are then sun-dried traditionalfor 5-10 days to beat down the moisture content to about $15-30 \%$. Alternatively, the nuts are subjected to oven drying at temperatures of $50{ }^{\mathrm{O}} \mathrm{C}, 4-5$ days reducing to the moisture content to $4-5 \%$. This process helps to enhance the de-husking; removing husk by pounding of the nut in a mortar and pestle and then subsequently roasting and cracking between two stones[3], [5].Pre-extraction stages like accumulation of fresh shea nuts, heating the fresh nuts and drying the kernel may affect the quality of kernel by increasing free fatty acid (FFA), Peroxide Value (PV) and fungal levels[3].In addition,polycyclic aromatic hydrocarbons are produced in the cause of smoking or roasting with open wood heating. The presence of these will hinder entry into the ,edible marketplace ${ }^{e c}$ in Europe and US because of their carcinogenic properties[3]. Unfortunately, often times, local producers do not have access to these requisite information or facility for maintaining the required quality standard.

\section{Volume 4 Issue 12, December 2015}




\section{International Journal of Science and Research (IJSR) \\ ISSN (Online): 2319-7064}

Index Copernicus Value (2013): 6.14 | Impact Factor (2014): 5.611

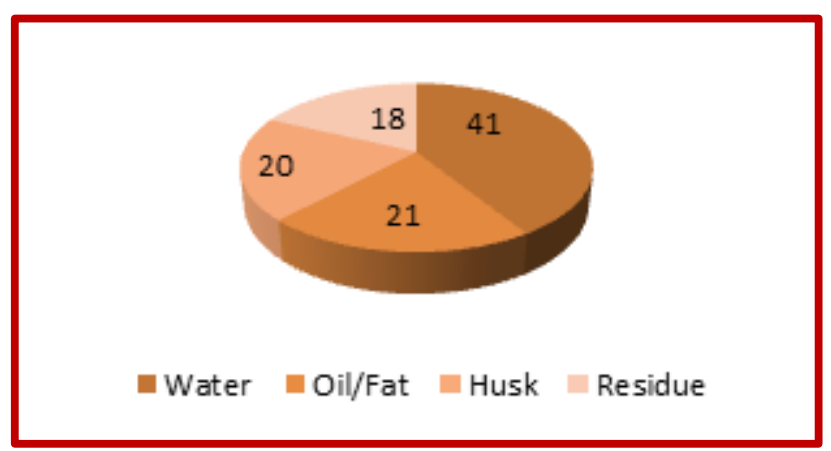

Figure 1: Composition of shea nut

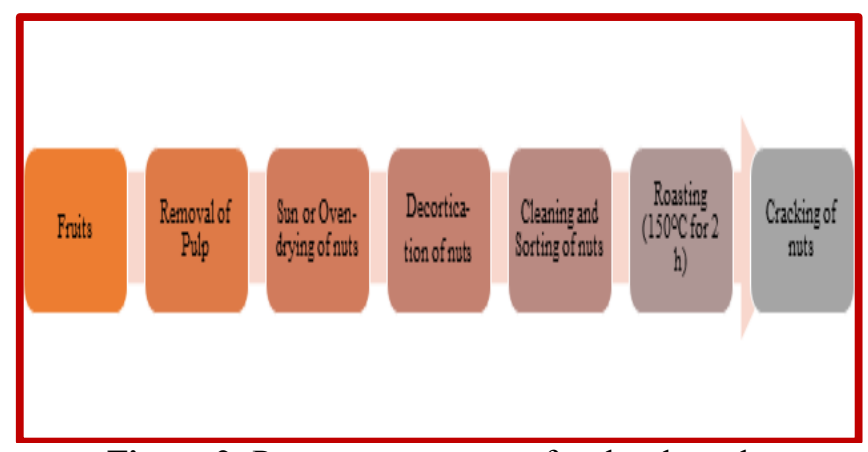

Figure 2: Pre-treatment stages for shea kernels

In the traditional method for butter extraction, the kernels are dried, crushed, ground and kneaded to form a paste[1], [2].The paste is poured into hot water $\left(85^{\circ} \mathrm{C}\right)$ and stand for 8 hs. A grey material is formed during the separation of the oily fat from the oil-water emulsion. This oily fat is then skimmed off the surface, clarified and heated into solid (shea butter). In solvent extraction method, about $250 \mathrm{~g}$ paste is poured into beaker; $120 \mathrm{~mL}$ of hot water at $85{ }^{\circ} \mathrm{C}$ is then added follow by $230 \mathrm{~mL}$-hexane. This is allowed to stand for $48 \mathrm{hs}$ to enable the oil to separate. Then the oil is decanted, allowed to solidify and packaged in glass vessels or aluminium foil[5].Solvent extraction method does give higher yield and other chemical and physical qualities of oil butter than the traditional extraction method of the extraction of shea butter[5].Ikyaet al.,[5] have recommend the use of solvent extraction method since it gives higher yield of shea butter, notwithstanding, the sensory qualities of the butter from traditional extraction method is better than the one from solvent extraction[5]. It is also worth using greener solvent (importantly $\mathrm{scCO}_{2}$ ) which are environmentally-friendly for the extraction of better quality shea butter which will be attracting to the buyers. Buyers prefer kernels with the following qualities: Free Fatty Acids (FFA) $<6 \%$, kernel fat content $45-55 \%$, water content $<7 \%$ and impurities $<1 \%$; or shea butter with white to yellow appearance, low impurities, low odour,low melting point, and high unsaponifiable fraction (the portion with therapeutic properties, $3-12 \%$ of total extract). In addition, manufacturers in the chocolate and other food industries prefer to buy the shea nuts as whole rather than the butter so that they can dictates the processing and quality of the final product; as well as the storage for longer time, because shea butter deteriorates more rapidly[1].Benin, Burkina Faso, Côte d'Ivoire, Ghana, Mali, Nigeria and Togo were known to produce shea Nut up to 606,500 MTs as of 1993-98 with Nigeria having the largest production of $355,000 \mathrm{MTs}[1]$.

\section{Composition/Properties of Shea Butter}

Shea butter contain many fatty acids; palmitic, margaric, stearic, oleic, linoleic, arachidic, eicosenoic, docosanoic tetracosanoic acids[5].Fatty acids in shea are mainly stearic, oleic, palmitic, linoleic, and arachidic. The Olein butteris low melting fraction (triacyl-glycerols high in oleic acid, e.g. OSt-O), while the Stearinbutter has high melting fat fraction (high in stearic acid, e.g. St-O-St). The long fatty chains in butter can degrade through, autoxidation into peroxides (measure as peroxide value) that can later break down into other chemicals including malodorousketones and aldehydes. This is catalysed by heat, certain metals (e.g. iron and copper)and ultra-violet light. Shea butter has unsaponifiables compounds (3-12\%) that are responsible for the therapeutic properties of shea butter, e.g. antioxidants (oil soluble tocopherols and water-soluble catechins) triterpenes (butyrospermol), phenols, sterols, karitene and allantoin. Triterpenes and vanillin are the main constituent of the unsaponifiable fraction of the shea butter. The main terpene in shea butter is thetriterpene alpha- amyrin[2]. Shea butter may be hydrogenated to increases the shelf life because it becomes more stable and easy to handle[2]. But hydrogenation can break down a lot of the unsaponifiable that give shea butter so many unique benefits. Most big companies produce hydrogenated shea butter. Hence locally made shea butter that is not hydrogentated is better in terms of the unique benefits.Different grades of shea butter have peculiar melting point which is related to their applications[2]. Butter could be fractionatedand tested for specific applications to maximize the potentials of the chemicals.

\section{Uses of Shea Butter and Shea Tree}

The shea tree themselves are used as shade for other crops in dry seasons. Also, the shea tree wood is hard, heavy and resistant to termite which makes it useful in building construction, manufacture of mortars, craft goods and charcoal. About 150,000 tonnes of shea tree kernel are consumed annually for various applications[3].Locally shea butter finds application in making soap[4].It enhances cicatrisation of umbilical cord after circumcision. The oil from shea seeds is used locally for frying and making sauces[1], [3].Shea butter has nutritive qualities including vitamins A, D, E, F.Since the 19th century, Africans have traded shea butter as a source of stearin (vegetable fat), particularly for the European chocolate industry, and as beneficial component of personal care products. Shea butter is used in the production of cocoa butter equivalents (CBEs) and in other confectionery industry[1],or improvers; say up to $5 \%$ content by weight is allowed under European Union (EU) regulations on chocolate[1].Countries that allow manufacture ofCBEs include the UK, Denmark, Sweden, Portugal, Ireland, Russia and Japan[1].Industrially, it is a feed stock in producing detergents,[1]lubricants, candles and paints[5]. Shea butter contains 90\% Triglycerides (saponifiable fraction) and $10 \%$ non-triglycerides (unsaponifiable fraction) hence it can be used in making soap[1],premium creams, lotions, skin care products[3], and margarine.Due to its unique blend of unsaponifiables (with UV-B absorbing properties) and essential fatty acid triglycerides, butter is a prime active ingredient for

\section{Volume 4 Issue 12, December 2015}




\section{International Journal of Science and Research (IJSR) \\ ISSN (Online): 2319-7064 \\ Index Copernicus Value (2013): 6.14 | Impact Factor (2014): 5.611}

cosmetics[1], [2], [4].It's effectively used for hair care products (shampoos and conditioners)[4].Lupeol in the butter is being considered for potential anti-cancer effect. Shea butter has $1 \%$ tocopherols making it one of the most antioxidant vegetable oils. Some sterols similar to those found in shea butter can reduce damage to cells in arthritis.It has antiinflammatory effects by calming redness and itching due to the alpha-amyrin in shea butter. Its anti-inflammatory effect is comparable to a popular branddexamethasone[2].It is used in treatment of leprosy and other ailments in Nigeria[5].Shea butter is good for treatment of eczema [2], [3]. It is useful against skin irritant and as soothing in sprains and strains. It does protect the skin from UV light damage by absorbing the UV with the presence of compounds like cinnamic acid esters which have strong UV absorbing properties[2], [3].Unsaponifiable (3-12\%) fraction of shea butter has therapeutic benefits, such as, UV protection, moisturising, regenerative, anti-wrinkle, anti-agingand prevent wrinkle formation [3], [4].These have resulted into worldwide growing demand for shea butter in personal care products as recognised by cosmetic industry[3].People in Africa in the past do apply shea butterto protect their skin from dryness and sunburn, treatment of chapped lips and feet, skin abrasions and blemishes. Thus far it is natural, moisturizer and healer of skin[2].It qualities defies any conventional lipids. As far back as 1940, evidence was that those using shea butter experience scarce skin disease and they had smooth skin. Importantly, it goes without saying that, there are lot more to be discovered from the butter in terms of its benefits. Thus, the uses of shea butter, an essentially biorenewable product are unlimited.

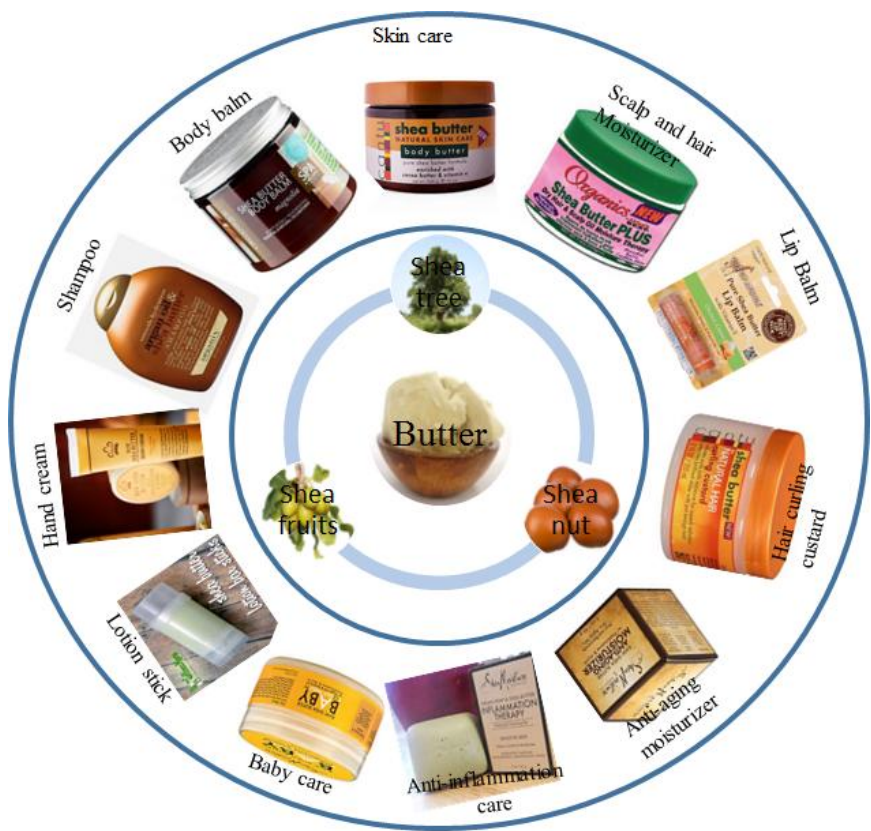

Figure 3: Some products containing shea butter

\section{Conclusion}

Shea butter is one of the world's most sustainable biorenewable products. It comes from shea trees that grow naturally in the grasslands of west and central Africa and do not need any irrigation, fertilizer or pesticides and can produce up to 180 years.It is environmentally sound and good for current ecologically sensitive market[4].These days of acute weather and climatic conditions that is affecting people s skin[6], shea butter will help in curing skin disease in addition to other unlimited benefits. In order to make the butter readily available and sustainable, there should be more globalised protection and plantation of the tree in West and Central Africa. Government and NGOs should support local people in processing butter[3], [7]. The butter can be maximized by fractionating and appropriating these fractions to specific applications. Greener solvents like supercritical carbon dioxide $\left(\mathrm{scCO}_{2}\right)$ can be used for shea butter extraction to have a better quality product to meet the needs of western markets like US and Europe.

\section{References}

[1] F. Inc., "Market and Technical Survey: Shea Nuts," Market and Technical Survey: Shea Nuts, 1999. [Online]. Available:

http://www.unctad.info/upload/Infocomm/Docs/Karite/M arket and Technical Survey Fintrac.pdf. [Accessed: $31-$ Jan-2015].

[2] Petworth, "Artful Teasing Guide to the Benefits of Shea Butter." [Online]. Available: http://colinsbeautypages.co.uk/wpcontent/uploads/2009/06/shea-butter-e-book.pdf. [Accessed: 10-Feb-2015].

[3] P. Lovett, "Production, transformation andmarketting in West Africa: WATH Technical Report No. 2," 2004.

[4] M. Pobeda \& L. Sousselier, "Shea butter: The revival of an African wonder."[Online]. Available: http://www.ceci.ca/assets/uploads/PDFFR/Karite/SheaButterRevivalAfricanWonder.pdf Accessed on 27/12/2015

[5] J. K. Ikya, L. N. Umenger\& A. Iorbee, "Effects of extraction methods on the yield and quality characteristics of oils from shea nut," J. Food Rsource Sci., vol. 2, no. 1, pp. 1-12, 2013.

[6] R. Sanjiv Grover, "Global warming and its impact on skin disorders," Indian J Dermatol Venereol Leprol, vol. 75, no. 4, pp. 337-339, 2009.

[7] A. O. Ademola \& O. B. Oyesola, "Assessment of shea butter processing among rural dwellers in Atisbo local government area of Oyo state, Nigeria," Eur. J. Bus. Soc. Sci., vol. 1, no. 6, pp. 1-08, 2012. 